\title{
Clues of Early Life: Dixon Island-Cleaverville Drilling Project (DXCL-DP) in the Pilbara Craton of Western Australia
}

\author{
by Kosei E. Yamaguchi, Shoichi Kiyokawa, Takashi Ito, Minoru Ikehara, \\ Fumio Kitajima, and Yusuke Suganuma
}

doi:10.2204/iodp.sd.7.04.2009

\section{Introduction}

The Pilbara Craton in NW Australia (Fig. 1) exposes one of the well-preserved and least metamorphosed greenstone belts in the Archean. Greenstone belts are normally composed of a complex amalgam of meta-basaltic and meta-sedimentary rocks. Sedimentary rocks of the greenstone belts are good targets to search for clues of early Earth's environment and life.

In recent years, several scientific drilling programs (e.g.: Archean Biosphere Drilling Project (ABDP), Ohmoto et al., 2006; Deep Time Drilling Project (DTDP), Anbar et al., 2007, Kaufman et al., 2007; PDP: Pilbara Drilling Project, Philippot et al., 2007) were successfully completed in the western Pilbara area, where 3.5, 2.9, 2.7, and $2.5 \mathrm{Ga}$ sedimentary units were drilled. However, there is a huge time gap in the samples drilled by ABDP and DTDP that represents middle Archean time, between $3.5 \mathrm{Ga}$ and $2.9 \mathrm{Ga}$ (i.e., $\sim 600 \mathrm{Ma}$, equivalent to the duration of the entire Phanerozoic). The Cleaverville-Dixon Island area of the coastal Pilbara terrain (Fig. 1) is suited to filling in the missing record. It contains well-preserved volcanosedimentary sequences (Cleaverville Group dated at $3.2 \mathrm{Ga}$ ) where hydrothermal vein systems, organic-rich siliceous sedimentary rocks, and iron-rich sedimentary rocks are developed (Kiyokawa et al., 2006). Such geological materials may be used to reconstruct past submarine hydrothermal

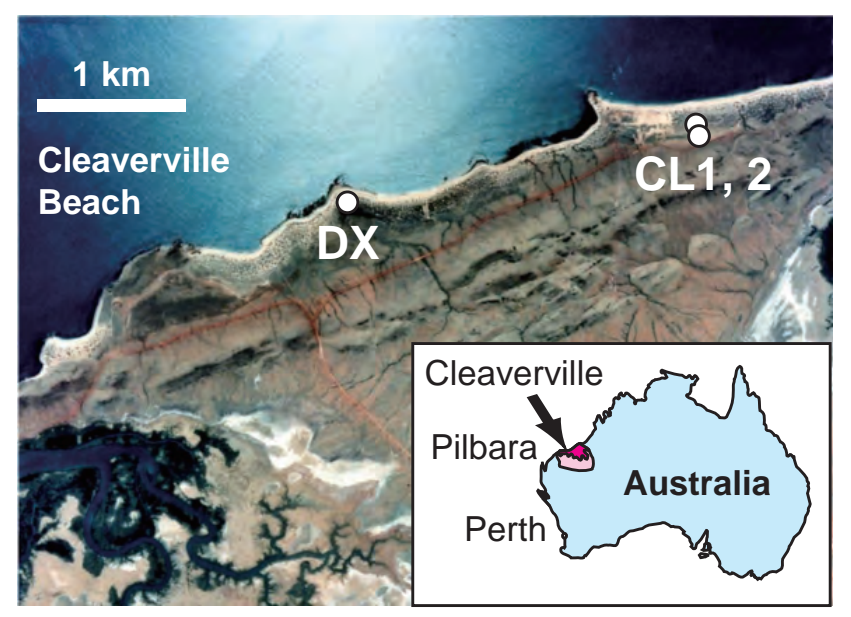

Figure 1. Aerial photo showing locations of drilling sites CL1, CL2, and DX for DXCL-DP in Cleaverville, northwestern coast of Pilbara district, Western Australia. Coordinates of the DX site are $20^{\circ} 39^{\prime} 21^{\prime \prime} \mathrm{S}$ and $117^{\circ} 00^{\prime} 04^{\prime \prime E}$. Aerial photo is taken from "Google Earth" (http:// earth.google.com/). activity and its influence on biological activity. Indeed, some attempts have been made to answer the key questions. However, the surface outcrops in this area are generally weathered to variable degrees; thus they are apparently not suitable for geo-biological and geochemical studies which require unaltered original chemical/isotopic compositions from the time of their formation in the middle Archean. Consequently, we carried out the "Dixon Island - Cleaverville Drilling Project (DXCL-DP)”, to obtain “fresh” samples from the sedimentary sequences in the Cleaverville-Dixon Island area.

\section{Scientific Objectives and Methods}

The most important objective of the DXCL-DP is to understand the nature of the middle Archean (3.2 Ga) marine environment influenced by hydrothermal activity, through detailed and systematic study of fresh drill core samples. This objective has been pursued through (a) detailed stratigraphy of the whole section, (b) inorganic geochemistry of sedimentary rocks, (c) organic geochemistry of carbonaceous sedimentary rocks (i.e., characterization of the carbonaceous materials including insoluble macromolecular matter), (d) study of "microfossils", (e) geochemistry (including stable isotopes) of sulfide in sedimentary rocks, and (f) paleomagnetic study on oriented core samples in order to explore the presence and direction of the geomagnetic field in the early Earth. Various geochemical investigations of shales and cherts are used (e.g., major, minor, trace, and rare earth element geochemistry; $\mathrm{C}_{\text {org }}, \mathrm{N}, \mathrm{S}$, and Fe isotope geochemistry, etc.) to fully extract the information from samples and to understand the influence of submarine hydrothermal activity on the biological and chemical fingerprints. From these data we intend to determine the original environmental information at the time of deposition.

\section{Drilling Targets and Geological Background}

Our drilling targets were deeply buried organic-rich black cherts and black shales of the Dixon Island Formation (DIF) and Snapper Beach Formation (SBF) (Fig. 2). Both formations belong to the $3.2 \mathrm{Ga}$ Cleaverville Group and are exposed along the coasts of the Cleaverville area and Dixon Island. The Cleaverville Group is a well-preserved submarine sequence affected only by low-grade metamorphism (prehnite-pumpellyite facies) without intensive deformation 


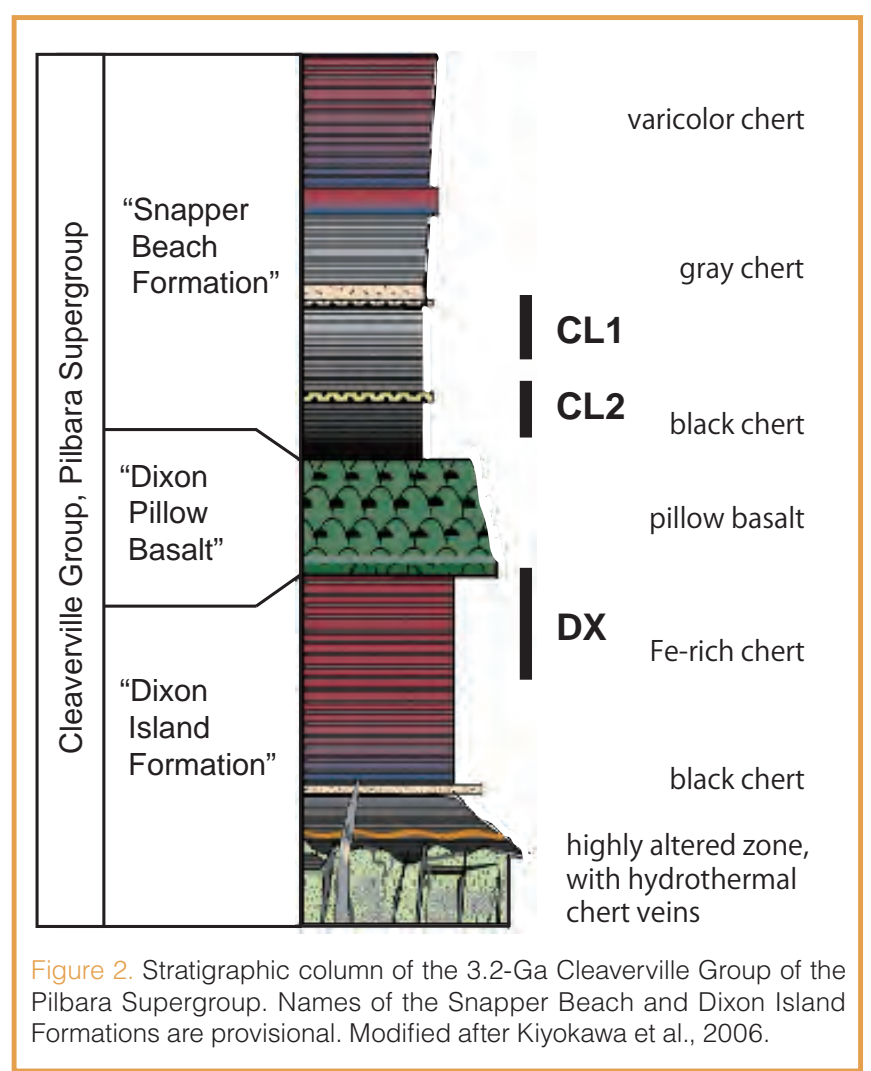

(Kiyokawa et al., 2002). It is composed of volcanic rock units and chemical-volcano-sedimentary sequences. Interpretation of its depositional settings diverges among rift, horizontal tectonics, accreted oceanic crust, or accreted immature island arc (Hickman, 1983; Van Kranendonk et al., 2006).

The 350-m-thick DIF in the lower part of the Cleaverville Group consists mainly of highly silicified volcanic-siliceous sequences that contain apparent microbial mats and fossilized bacteria-like structures within black chert and also includes a komatiite-rhyolite sequence bearing hydrothermal veins. The $>300$-m-thick SBF in the upper part of the Cleaverville Group contains a thick unit of reddish shale, bedded red-white cherts, and a banded iron formation. It also contains chert fragments bearing pyroclastic beds bearing chert fragments (Kiyokawa et al., 2006). We selected two coastal sites at the eastern part of the Cleaverville Beach for drilling (Fig. 3). The first site (CL1 and CL2) was intended to drill through the lower part of the SBF (distance between holes is $60 \mathrm{~m}$ along the core dip direction), and the other is the DX site which was targeted to drill the upper DIF.

\section{Drilling Results}

DXCL-DP was successfully completed in summer 2007 after continuous drilling from 31 July to 10 August. The orientation of the core, being perpendicular to the bedding plane, is $52^{\circ}$ dip to the southwest for the CL1 and CL2 site
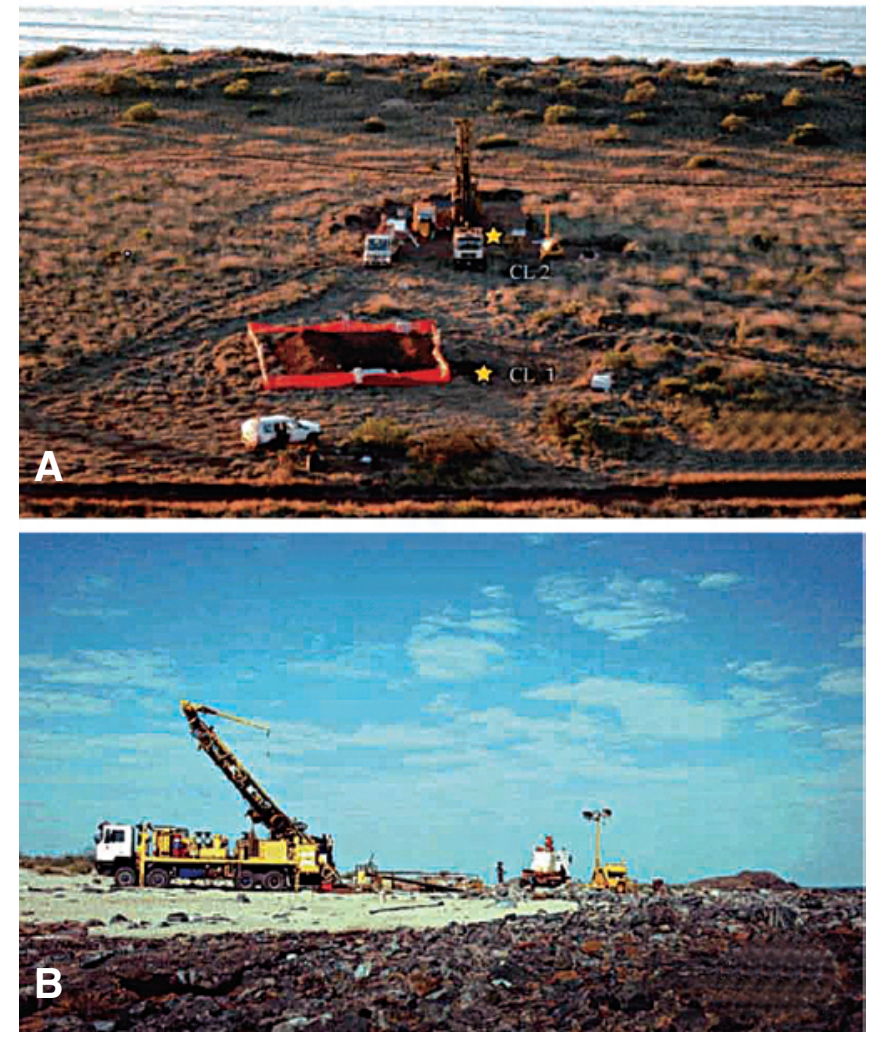

Figure 3. Photographs of drilling sites for DXCL-DP. [A] CL1 and CL2, and $[B] D X$.

and $52^{\circ}$ dip to the northwest for the DX site. Orientations of the core samples were taken using "Ezy-Mark" oriented system (2iC Australia Pty Ltd). As a cooling media during drilling, freshwater was used at CL1 and CL2 sites, and seawater at DX site; for both, partially hydrolyzed polyacrylamide lubricant was added. A summary of information on drilling sites (core length, direction, bedding, etc.) is presented in Table 1. Stratigraphic columns of CL1, CL2, and DX are shown in Fig. 4, and an example of drillcore (DX) in a core tray is shown in Fig. 5.

CL1. The CL1 drill core (66.1 m long; Fig. 4), covering the lower part of the SBF, consists of two units: black shale and reddish shale. The black shale unit was subdivided into five subunits (BS1 to BS5). BS1 (39.4-45 m) consists of highly fragmented but organic-rich massive and laminated black shales. BS2 (49-62 m) and BS3 (71-88 m) subunits consist of massive and partly laminated black shales. BS4 (92-94 m) and BS5 (99-105 m) subunits consist of organic-rich massive able 1. Summary of logistical information on DXCL-DP drill cores.

\begin{tabular}{|l|c|c|c|}
\hline & \multicolumn{3}{|c|}{ DXCL-DP Drill Core } \\
\hline Drilling Site & CL1 & CL2 & DX \\
\hline Latitude & $117^{\circ} 01^{\prime} 28.8^{\prime \prime}$ & $117^{\circ} 01^{\prime} 20.1^{\prime \prime}$ & $117^{\circ} 00^{\prime} 05.9^{\prime \prime}$ \\
\hline Longitude & $20^{\circ} 39^{\prime} 06.7^{\prime \prime}$ & $20^{\circ} 39^{\prime} 35.0^{\prime \prime}$ & $2^{\circ} 39^{\prime} 43.6^{\prime \prime}$ \\
\hline Depth to Start Drilling & $39.4 \mathrm{~m}$ & $47.6 \mathrm{~m}$ & $47.7 \mathrm{~m}$ \\
\hline Depth to Finish Drilling & $105.3 \mathrm{~m}$ & $92.0 \mathrm{~m}$ & $148.3 \mathrm{~m}$ \\
\hline Total Drill Core Length & $66.1 \mathrm{~m}$ & $44.4 \mathrm{~m}$ & $100.15 \mathrm{~m}$ \\
\hline Stratigraphic Thickness & $40.7 \mathrm{~m}$ & $27.3 \mathrm{~m}$ & $61.5 \mathrm{~m}$ \\
\hline Core Directon & $160^{\circ}$ & $159^{\circ}$ & $315^{\circ}$ \\
\hline Dip & $52^{\circ}$ & $50^{\circ}$ & $52^{\circ}$ \\
\hline
\end{tabular}


black shale with some fine sandstone layers. The laminated black shales with pyrite nodules occur at the deepest (but stratigraphically the uppermost) part. This unit partly contains graded thin sandstone beds with cross lamination. The reddish shale unit is either mostly fragmented laminated red-brown-black shale (44-49 $\mathrm{m}$ and $62-71 \mathrm{~m})$ or well-laminated reddish to black shale (86-88 $\mathrm{m}$ and 95-99 m). The uppermost section down to $53 \mathrm{~m}$ depth is strongly fragmented. Changes of the bedding orientation occurred at 54-57 m, 60-62 m, 72-75 m, 80-84 m, and 89-92 m depth ranges that are accompanied by fragmentation of the rocks.

CL2. The CL2 drill core (44.4 m long; Fig. 4), covering the lowest part of the SBF, consists of three units: weathered

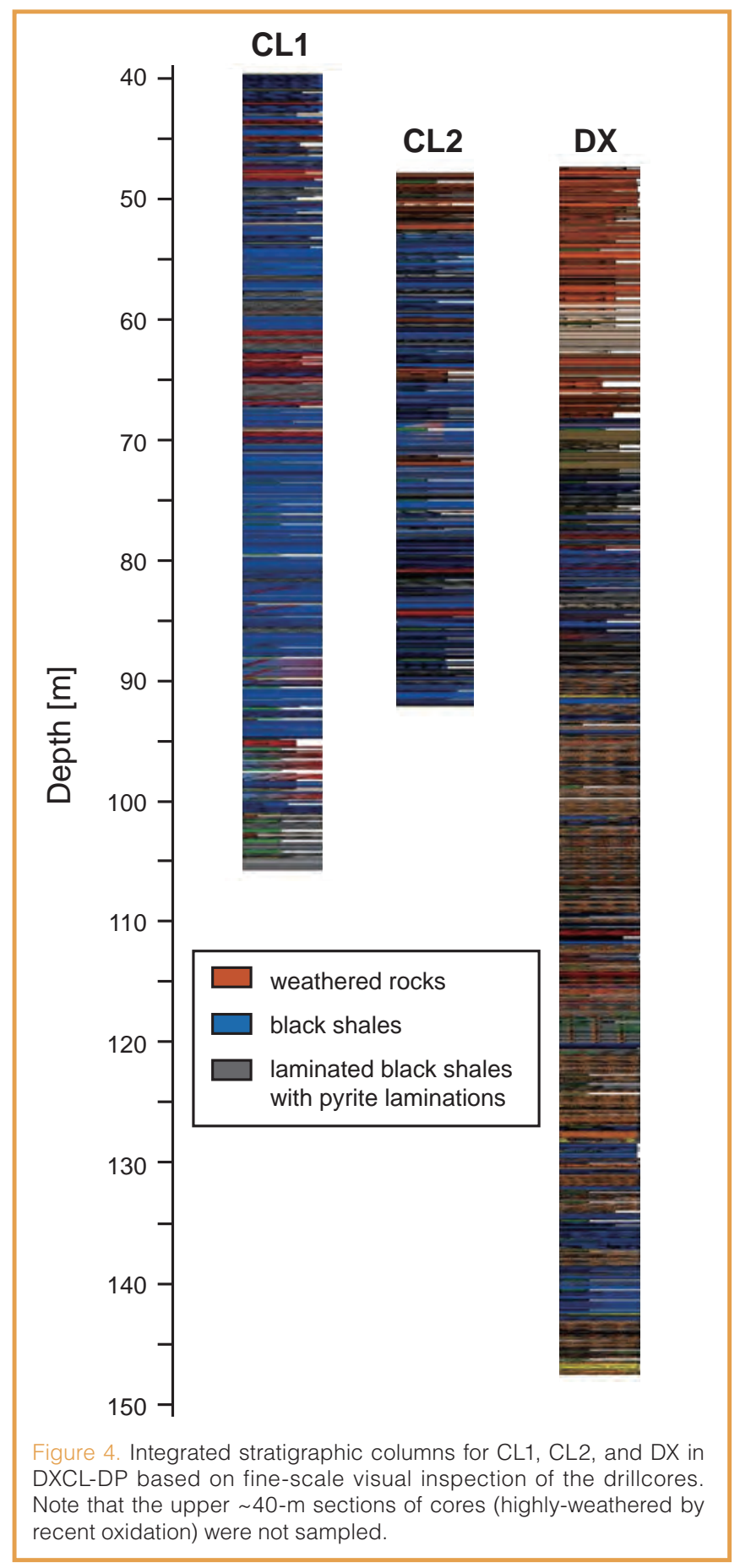

yellowish-brown rock (WY), black shale (BS), and reddish shale (R) units. Boundaries between each units are highly fragmented. The WY unit, containing laminated white chert, is highly weathered. The BS unit was subdivided into five subunits, BS1 to BS5. Each unit mainly consists of massive black shale with well-laminated black shale and silt bed, and contains some fine sandstone with cross lamination. The $\mathrm{R}$ unit was also subdivided into five subunits (R1 to R5), which consist of reddish massive shale, white chert, and massive and well-laminated black-gray-red shale. The color changes between red and brown are gradual. The CL2 drillcore is generally more fragmented than CL1 and DX drillcores. Bedding orientation slightly changes at $75-76 \mathrm{~m}$ depth and 81-82 m depth.

DX. The DX drill core (100.2 m long; Fig. 4), covering the upper part of DIF, consists of four units: highly fragmented/ deformed and well-laminated black shale (69-88 m, with disturbance at $85-88 \mathrm{~m}$ ); well-laminated black shale with pyrite lamina (88-149 m; a partly yet highly deformed section at 101-110 m; see Fig. 5) with several $\mathrm{cm}$-thick pyrite veins and $10-50-\mathrm{cm}$-thick massive sulfides at 138-139 $\mathrm{m}$ and 144-149 m depth ranges; massive and finely-laminated black shale; and reddish shale (110-118 m) units associated with

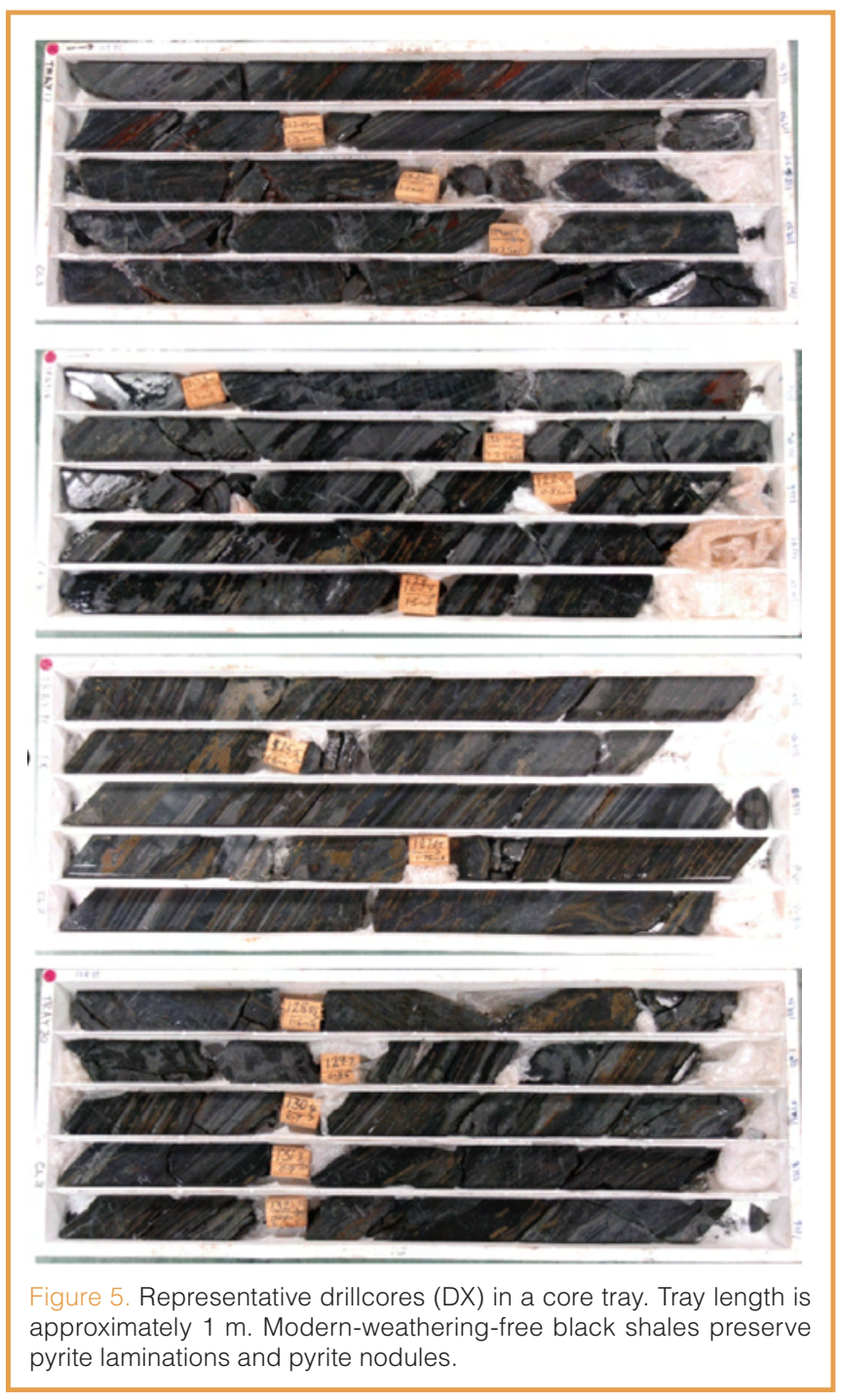


deformed/fragmented zones. The normal dip of the DX drillcore is approximately $50^{\circ}$. Gradual changes in the dip orientation are observed at the 110-123 $\mathrm{m}$ depth range that exhibit a few meter-scale open folds. The uppermost $\sim 70 \mathrm{~m}$ of the drillcore DX is generally highly weathered. Its upper part (47.9-59 $\mathrm{m}$ ) is massive and reddish, the middle part (59-63 m) contains bleached materials, and the lower part $(63-69 \mathrm{~m})$ is red but preserves the chilled margin structure of pillow basalts.

\section{Summary}

"Dixon Island-Cleaverville Drilling Project (DXCL-DP)" was successfully completed in summer 2007. Three holes were cored, the CL1 and CL2 cover the Snapper Beach Formation, while the DX drillcore covers the Dixon Island Formation, both of which belong to the Cleaverville Group. The CL1 and CL2 drillcores consist mainly of organic-rich massive black shales with little cross-laminated fine sandstone, and the DX drillcore contains very finely laminated black shales with lamination and veins of pyrite and weathered pillow basalt. These sulfide-containing black shales are not found anywhere in surface outcrops. It is the first discovery of these geological units.

A systematic combination of geological, sedimentological, geochemical, and geobiological approaches to the drillcore samples will be applied to obtain critical information on the characteristics of the samples and to understand the influence of submarine hydrothermal activity on the biological and chemical fingerprints. From these we intend to reconstruct the environmental conditions at the time of deposition.

\section{Acknowledgements}

We thank A.H. Hickman, M. Nedachi, T. Urabe, M. Doepel, K. North, K. McLeod, G. McLeod, and J. Williamson for their suggestions and help throughout the course of the drilling project. We thank GSWA Shire of Roebourne for permission for drilling in the Pilbara coast. This research was financially supported by grants-in-aid from the Japanese Ministry of Education, Culture, Sports, Science and Technology (MEXT, Grants \#14340153 and 18253006) and by the Nippon Steel Corporation.

\section{References}

Anbar, A.D., Duan, Y., Lyons, T.W., Arnold, G.L., Kendall, B., Creaser, R.A., Kaufman, A.J., Gordon, G.W., Scott, C., Garvin, J., and Buick, R., 2007. A whiff of oxygen before the Great Oxidation Event? Science, 317:1903-1906, doi:10.1126/science. 1140325.

Hickman, A.H., 1983. Geology of the Pilbara Block and Its Environs. Geological Survey of Western Australia, Bulletin 127, 268 p.

Kaufman, A.J., Johnston, D.T., Farquhar, J., Masterson, A.L., Lyons, T.W., Bates, S., Anbar, A.D., Arnold, G.L., Garvin, J., and Buick, R., 2007. Late Archean biospheric oxygenation and atmospheric evolution. Science, 317:1900-1903.
Kiyokawa, S., Ito., T., Ikehara, M., and Kitajima, F., 2006. Middle Archean volcano-hydrothermal sequence: Bacterial microfossil-bearing 3.2 Ga Dixon Island Formation, coastal Pilbara terrane, Australia. Geological Society of America Bulletin, 118:3-22, doi:10.1130/B25748.1.

Kiyokawa, S., Taira, A., Byrne, T., Bowring, S., and Sano, Y., 2002. Structural evolution of the middle Archean coastal Pilbara terrain, Western Australia. Tectonics, 21:1-24, doi:10.1029/2001TC001296.

Ohmoto, H., Watanabe, Y., Ikemi, H., Poulson, S.R., and Taylor, B.E., 2006. Sulphur isotope evidence for an oxic Archaean atmosphere. Nature, 442:873-876, doi:10.1038/nature05044.

Philippot, P., Van Zuilen, M., Lepot, K., Thomazo, C., Farquhar, J., and Van Kranendonk, M.J., 2007. Early Archaean microorganisms preferred elemental sulfur, not sulfate. Science, 317:1534-1537, doi:10.1126/science.1145861.

Van Kranendonk, M.J., Hickman, A.H., Smithies, R.H., Williams, I.R., Bagas, L., and Farrell, T.R., 2006. Revised lithostratigraphy of Archean supracrustal and intrusive rocks in the northern Pilbara Craton, Western Australia. Geological Survey of Western Australia. Record 2006/15, p. 63 .

\section{Authors}

Kosei E. Yamaguchi, Precambrian Ecosystem Laboratory, Japan Agency for Marine-Earth Science and Technology (JAMSTEC), 2-15 Natsushima, Yokosuka, Kanagawa, 237-0061, Japan, and NASA Astrobiology Institute (NAI), Present address: Department of Chemistry, Toho University, 2-2-1 Miyama, Funabashi, Chiba 274-8510, Japan, e-mail: kosei@chem.sci.toho-u.ac.jp.

Shoichi Kiyokawa, Department of Earth and Planetary Sciences, Kyushu University, 6-10-1 Hakozaki, Fukuoka 812-8581, Japan.

Takashi Ito, Faculty of Education, Ibaraki University, 2-1-1 Bunkyo, Mito, Ibaraki 310-8512, Japan.

Minoru Ikehara, Center for Advanced Marine Core Research, Kochi University, 200 Monobe, Nankoku, Kochi 783-8502, Japan.

Fumio Kitajima, Department of Earth and Planetary Sciences, Kyushu University, 6-10-1 Hakozaki, Fukuoka 812-8581, Japan.

Yusuke Suganuma, Ocean Research Institute, University of Tokyo, 1-15-1 Minamidai, Nakano, Tokyo 164-8639, Japan. 